\title{
Geographical Modules of COVID-19 Pandemic in Bangladesh: Social Response and Action Taken
}

\author{
Mohammad Tareq Alam ${ }^{1}$, Md. Ashrafuzzaman ${ }^{1 *}$, Nazmir Nur Showva ${ }^{1}$, \\ Mansura Ahmed ${ }^{1}$, Faruq Ahmed Jewel ${ }^{2}$, Md. Asadur Rahman ${ }^{1}$ \\ ${ }^{1}$ Department of Biomedical Engineering, Military Institute of Science and Technology (MIST), Mirpur Cantonment, Dhaka-1216, Bangladesh . \\ ${ }^{2}$ Department of Computer Science and Engineering, Dhaka University of Engineering \& Technology (DUET), Gazipur-1700, Bangladesh.
}

Received 08 November 2020; Revised 03 March 2021; Accepted 18 March 2021; Published 27 April 2021

\begin{abstract}
Objectives: This research attempts to figure out a comparative pattern of the social response from the peoples of Bangladesh as well as different communities and regarding actions taken by the government during the COVID-19 pandemic in Bangladesh. Else, this study also investigates the shortcomings of the different wing authorities of the Bangladesh Government to reach people of every corner of this country. Methods: In this research, different facts are analyzed from a statistical point of view. Authentic sources like reputed national and international newspapers, governmental release documents, release notes of WHO, etc. were considered for data collection to realize this country's preparations against the COVID-19 pandemic. Results: From the statistical analysis, this study found that different government authorities partially failed to communicate the measures of the government to the wider public audience. This study has shown that having more tests could have prevented the spread of the virus in Bangladesh. The strong lockdown measures taken by the government were not enough as the population of this country is huge and it is really difficult to maintain social distance in a densely populated country like Bangladesh. Conclusions: The socio-economic condition and decision-makers' shortcomings could have been overcome if the right plan and action had been taken at the right time. Until the vaccine is available it is recommended that people should keep social distance while going outside, using masks and protection should be mandatory. Furthermore, more health care professionals should be hired and trained to fight this virus.
\end{abstract}

Keywords: Bangladesh; COVID-19; Social Response; Health Sector; Risk Mitigation.

\section{Introduction}

Serious intense respiratory condition coronavirus (SARS-CoV-2), prevalently alluded to as COVID-19 is a transmittable malady that was first recognized in December 2019 in Wuhan. Just after one and a half months, it became a transmissible pandemic. The world has been facing a big crisis causing around 800 thousands of deaths by COVID-19 across the world [1,2] and therefore, it has been declared as a pandemic by World Health Organization (WHO) on March 11. Originating from Wuhan in Hubei province in December 2019, it has spread rapidly in China as well as in other countries. As of August 06, 2020; 7,06,041 people had died by COVID-19 and 1,87,27,530 persons have been infected (John Hopkins, 2020). Though the highest infected rate is in the USA $(4,903,385)$, the highest death toll is also in the USA 160,402 . Despite a very strong health care system, the Western big economies are

* Corresponding author: ashezaman@gmail.com; ashraf@bme.mist.ac.bd

\section{doi) http://dx.doi.org/10.28991/SciMedJ-2021-03-SI-4}

$>$ This is an open access article under the CC-BY license (https://creativecommons.org/licenses/by/4.0/).

(C) Authors retain all copyrights. 
struggling to curve the death toll. In comparison to the world, the number of infected cases in Bangladesh remained in control until April 2020 [3, 4]. There were only 88 and the death toll just $9^{\text {th }}$ on $5^{\text {th }}$ April 2020. The country went for complete lockdown on the $26^{\text {th }}$ of March for two weeks and it is to be extended till 14th April. The government has been reintegrating social distancing and quarantine for all. Besides, they are claiming that Bangladesh is ready for fighting COVID-19 despite Dhaka's centric low number of tests and lack of Personal Protective Equipment (PPE) for the frontline fighters including doctors, nurses, and volunteers. The response of different countries differs due to social structure, economic capacity, and resources [5]. In these circumstances, this study attempts to bring public opinion regarding different measures of the Bangladesh government in the academic field. This research aims to understand to what extent the public perception of the government's measures corresponds to the facts. This research shows an epistemological contribution regarding public opinion and the government's measures to fight COVID-19 in a broader conceptual field which will significantly contribute to the governments' understanding of public perception [6].

\subsection{Research Methodology}

The research method starts with understanding the overall situation of the COVID-19 pandemic in Bangladesh. Authors collected data from different sources like WHO online published resources, Bangladesh Government website published data also conducting an online survey using google spreadsheet and google form. The authors prepared a questionnaire for a survey and shared it on social media for a response. The collected data is then brought into a structure and stored into a google spreadsheet as an online database. Also, reading and analyzing different data from various media are utilized to find the facts and explain the situation. This method also found reasons for the lack of necessary action and social response against the COVID-19 attack in Bangladesh. Find different facts related to social response and action taken by the Bangladesh government based on collected data. Data analysis using statistical methods provided different reports by which this research work presents the situation graphically. This model tries to discuss the possible solutions to the problem of social response and action taken. Preparing general advice for risk mitigation is also a goal for this article. The authors tried to verify and validated the model based on comparing collected data and results. A flow chart given in Figure 1 explains the steps of the research methodology.

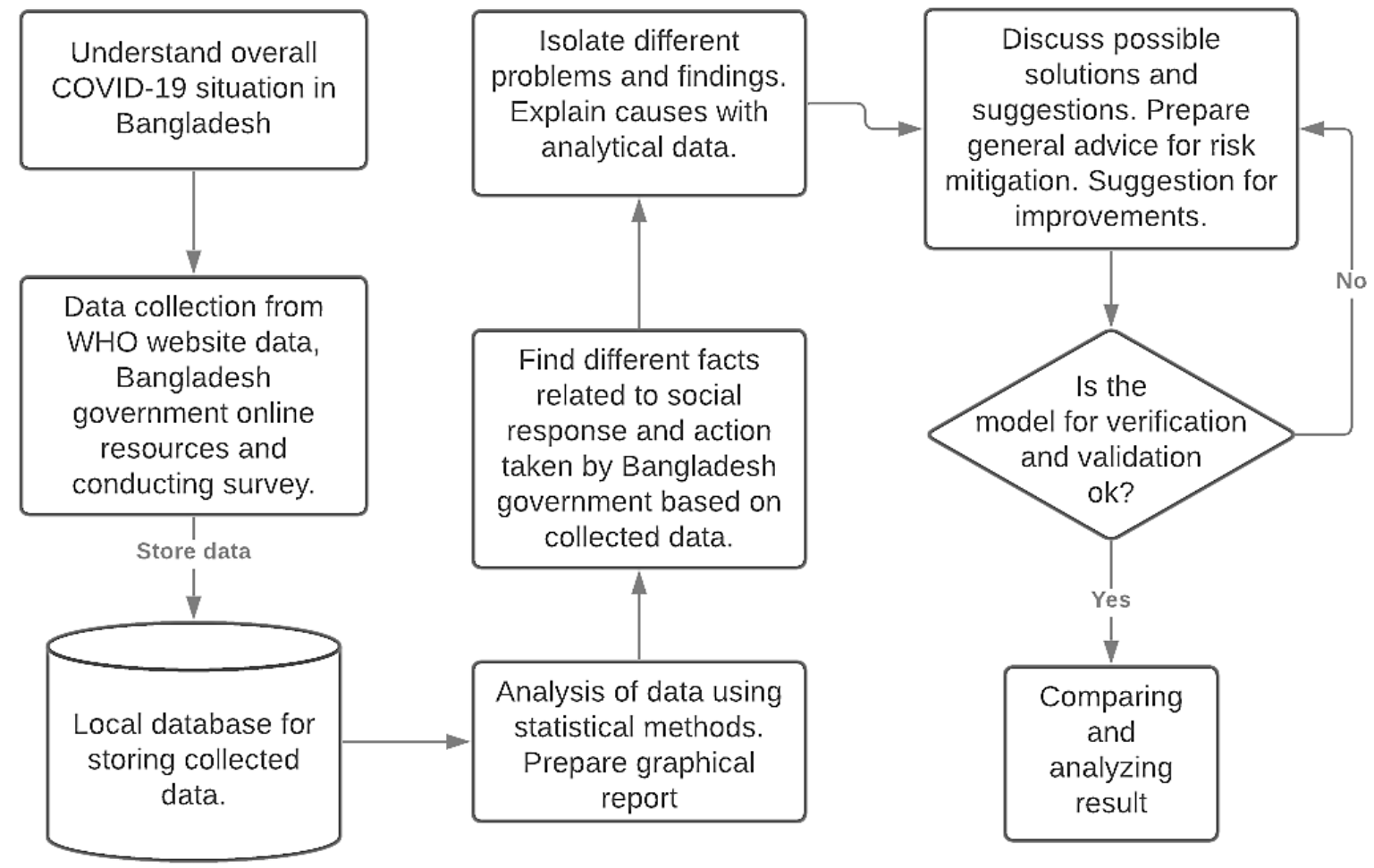

Figure 1. Research methodology flow chart

\subsection{Health Sector in Bangladesh}

The open division is to a great extent utilized for out-patient, inpatient, and preventive consideration, while the private part is essentially utilized for outpatient and in-understanding remedial consideration. Service of health and family welfare liable for the arranging and the executives of medicinal, preventive just as motivators wellbeing administrations to the nation's populace. Be that as it may, in urban territories, essential wellbeing administrations are necessary. For Local Government, Ministry of Rural Development and Cooperation since the last part of the 1990s, the Bangladesh government and its advancement accomplices have followed a segment-wide methodology in Health, 
Nutrition and Population Sector. Service of Health and Family Welfare is now executing for Health, Population, and Nutrition Sector Program 2017-2022 [7, 8]. The current government has made moves to re-start PHC administrations to direct network centers. These people group facilities, one for every 6000 locals. The strategy in such a manner is to hand over the duty of the wellbeing of the individuals to the individuals themselves. Utilitarian people group centers with sufficient staffing, supplies, and coordination. It is important to quickly systematize to improve the administrations of solid association and Upazila level conveyance of preventive and therapeutic administrations at PHC level particularly for weak ladies, kids, and peripheral populace. In the open part, Upazila wellbeing edifices, and region emergency clinics, are giving therapeutic care at essential and auxiliary levels separately. Tertiary level corrective consideration is given generally at national and divisional levels through enormous emergency clinics related to clinical instruction organizations. Generally medicinal, preventive, motivation, and recovery administrations are given by open segment offices and organizations.

\subsection{Bangladesh's Response to COVID-19}

Before going into detail in Figure 2, we can see a consistent increase of patients who, unfortunately, died due to COVID-19. This is according to data from IEDCR, but there are many more patients who died with COVID-19 symptoms in Bangladesh which have not been registered in the above graph [1,9]. Since the onset of the COVID-19 pandemic last December, Bangladesh has had a long preparation time to prepare as the first confirmed case was found in early March. Bangladesh soon facilitated the return of 312 students to China, studying at universities adjacent to Wuhan and Hubei, and placing them at Haji Camp, Dhaka [10]. Besides, the government bought some thermal scanners, while some of them soon died. For this reason, a mandatory temperature check was stopped. Also, institutional quarantine was confirmed too late for confirmed cases. For those returning from abroad, only the option of domestic quarantine was made until it detected high temperatures at the airport. Beginning in March, some government ministers, including the health minister, said the government was ready to deal with the crisis. But some cabinet ministers' comments on COVID-19 have made the government uncomfortable. Besides, Bangladesh lacked dedicated hospitals, test kits, laboratories, training for front-line fighters, PPE, etc. as of $29^{\text {th }}$ March. As of $30^{\text {th }}$ March, Bangladesh has established 10 dedicated hospitals for COVID-19 patients [10,11]. The Health Minister said that as of March 29, there are 90,000 test kits in Bangladesh, but 60 percent of these kits were not the gold standard. That is why IEDCR did not use those kits. So far, Bangladesh is one of the least tested countries in the world. The country tested only a few cases despite the IEDCR's hotline numbering around 800,000 calls.

Among all measures, WHO (2020) is making a nationwide effort for two important social measures; Social distancing or self-isolation; and lockdown. The Bangladesh government has started social distancing since late March, arguing that there may be an outbreak of COVID-19 in this method. Social distancing is a method of isolation that keeps people apart from meeting friends, peers, or any other person. Fernandez-Villaverde and Jones (2020) [5] defined social isolation as a state of absence of contact between people and society. Scientific data and academic researchers have also found that the number of individuals infected; through social distancing, models can be significantly reduced [12]. For example, Durmuş et al. (2020) [13] have found in their research that where social distancing was applied, there was a substantial decline in the level of infecting people. Social deformity has been seen as the best way to prevent the spread of the disease and almost every country is being advised to follow it. The flattened curve will enable the slow spread of this virus and help isolate and treat patients. China is an example that can control the spread of this virus after two months through its social distancing and lockdown methods. Scientists around the world are also suggesting social solutions as the ultimate solution.

Therefore, Bangladesh's position to urge social distancing is matched by scientific advice. Separate reports in the media (Daily Star, 2020) showed that despite the hard work of law enforcement agencies, people from many places in Bangladesh are not distanced and have violated the rule. In this situation, albeit social distancing is an essential policy, it is difficult for people to follow this method because it has serious economic and mental health effects [14]. People have significant mental issues when living alone at home or just with family [15]. Fernandez-Villaverde and Jones (2020) [5] wrote that a detrimental effect will be a by-product of social distancing if measures are not taken to reduce this mental pressure for people living at home. This was one of the reasons why the UK Prime Minister was delayed to go for a full shutdown. Low-income people will be heavily affected, and the Western world has announced separate contingency plans for a billion-dollar budget for them. To ease the economic crisis facing the poor, the Prime Minister of Bangladesh declared a 72,750 crore BDT bailout for RMG and other business sectors to reduce the economic impact of COVID-19. The first will be for 5000 crore RMG sectors, the second will be given as working capital to 30,000 affected industries and service sectors, the third will be disbursed as working capital to small and medium enterprises, fourth will be to Bangladesh Bank Development Fund. Be raised from $\$ 3.5$ billion to $\$ 5$ billion to help importers of raw materials and the last Rs.5000 crore will be for pre-shipment credit refinance scheme under Bangladesh Bank $[9,16]$. These stimulus packages will be primarily a soft loan policy to assist the private sectors in Bangladesh. But these packages surprisingly did not incorporate the agro-based schemes. She requested people not to engage in a panic buy and businessmen not to be inhuman in this crisis. Nonetheless, her packages lacked detailed 
plans for how low-income people and people without fixed income would lead their lives during these lockdown periods. Also, Bangladesh Bank will not declare anyone as a loan defaulter till next June (The Dhaka Tribune, 25 March 2020). On the other hand, returnees from abroad are advised to stay in 14days quarantine since late March (The Dhaka Tribune, 2020).

On 26 March, Bangladesh closed all public and private offices, keeping only emergency services open (The Daily Star, 2020). WHO (2020) advised Bangladesh to undergo a full or partial lockdown. Since the situation of lockdown, Bangladesh has received a few new cases of COVID-19 without any reason (BBC, 2020). Despite criticism in the media, some people died of cough and breathing problems in some places in Bangladesh; The IEDCR dismissed any further cases. The rapid proliferation of COVID-19 led China to shut down all public-private offices and complete the shutdown of public transport (BBC, 2020). The lockdown situation persists in some parts of China and China has shown that the rate of spread slows down and the virus can only be contained within infected people. This method was applied very late in Italy. Other European countries, UK, USA, have followed the lockdown method due to a significant increase in the number of cases. For example, the UK imposed a lockout on 23 March, when the cause of work began to increase significantly. The lockdown will not decrease the number of infected cases, but it will reduce the chances of infecting new people and help social isolation. There is an important reason that China can prevent the spread of the disease after a certain period due to large-scale lockout as well as other public health measures [17].

\section{Data Presentation and Analysis}

\subsection{COVID-19 Test Centers in Bangladesh}

Below listed date-wise opening of COVID-19 testing centers:

26 $^{\text {th }}$ March-April, 2020 - When the world has already started lockdown in many countries, Bangladesh started lockdown from March 26. At that time many workers from Italy and other countries came to Bangladesh carrying the potential COVID-19 virus and the airport could not ensure the quarantine period for those passengers. Those passengers went to their homes where the virus started spreading from them. The only test center available at that time was IEDCR and the number of tests done was very low each day.

$2^{\text {th }}$ April 2020- First private COVID-19 testing center opens in Rupganj, Narayanganj named Gazi COVID-19 PCR Lab.

22 $^{\text {nd }}$ May 2020- Government affirmed 17 private testing centers. Among them, 14 are situated in Dhaka which is: icddr,b, Square Hospital, Evercare Hospital, Praava Health Bangladesh Limited, Ibne Sina Medical College Hospital, United Hospital, Enam Medical College Hospital, Biomed Diagnostics, Anwer Khan Modern Medical College Hospital, Lab Aid Hospital, Bangladesh Institute of Health Science and General Hospital, Care Medical College Hospital, DMFR Molecular Lab and DNA Solution Limited [10, 18, 19]. The performed COVID-19 test and new cases found from March to August are presented in Figure 2.

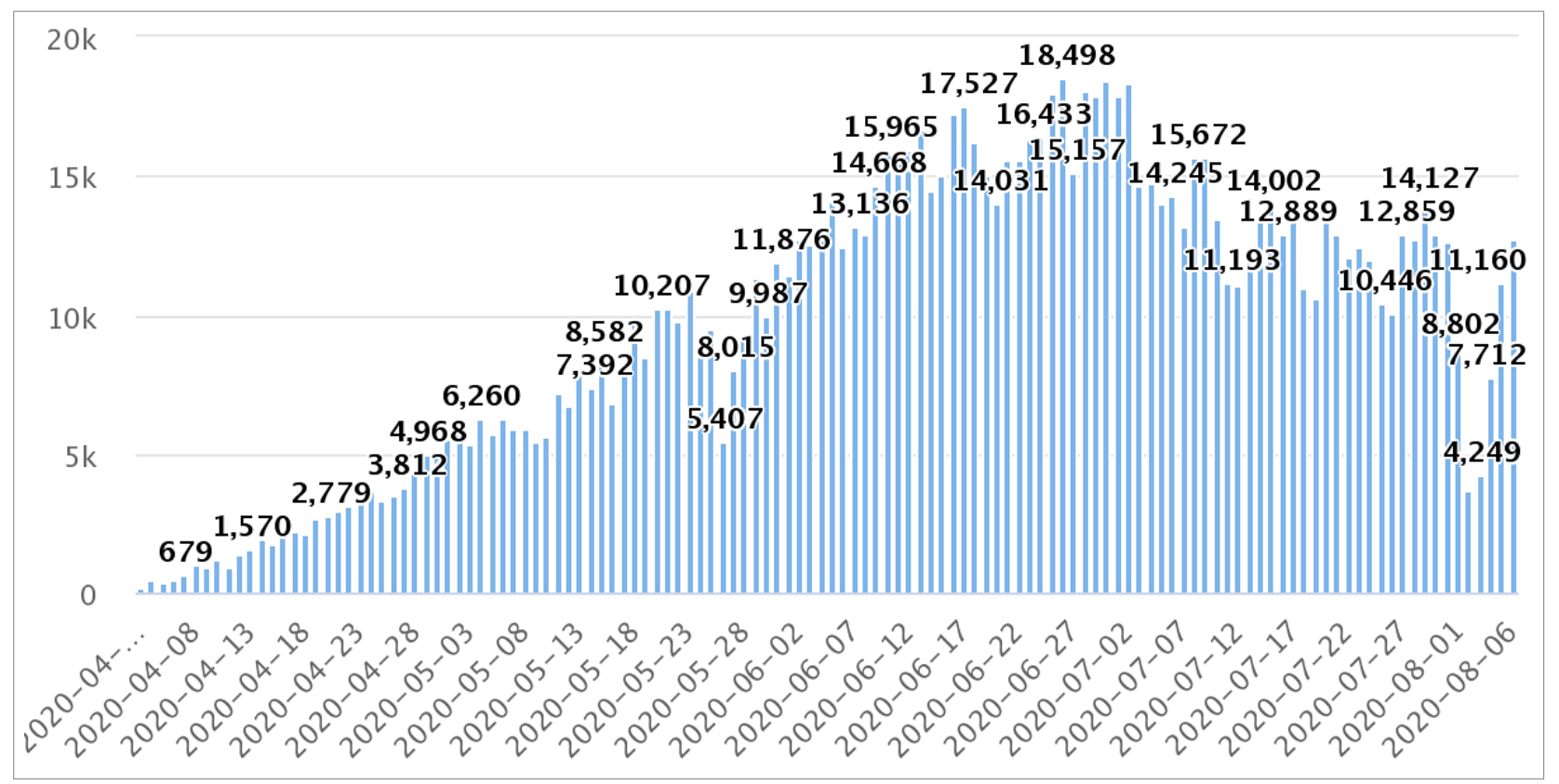

Figure 2. The number of tests performed in Bangladesh from March to August 2020 


\subsection{COVID-19 Test Facilities Inadequacy}

Five weeks after the first COVID-19 cases were detected in Bangladesh, the IEDCR tested only 11,223 people, with approximately 68 trials per million populations (Figure 2). It is most likely among the nations positioned most exceedingly terrible for the nCoV-2 test rate, even though the death rate is relatively high. It ought to be noticed that in the initial 3 weeks after the first COVID-19 case recognition in Bangladesh, IEDCR was the main clinical office in the nation of 180 million individuals, and the everyday preliminary rate stayed under 100 every day. Centralization of COVID-19 indicative centers is to some degree conceivable, as most emergency clinics don't have a satisfactory number of Personal Protection Equipment (PPE). Be that as it may, this left an awful condition of the mass of individuals and wellbeing laborers. Because of the joined absence of PPE and indicative testing ability, dread, and tension expanded among the populace everywhere, and numerous wellbeing laborers would not offer any types of assistance. With much analysis from different segments, the nation's wellbeing specialists at long last chose to broaden its test number from 3rd April. Right now (April 11, 2020), there are 17 labs in the nation dealing with the testing of potential instances of COVID-19, and a couple of more research centers are being set up in different regions, including Shahjalal University of Science and Technology additionally incorporates Sylhet [20, 21]. From May to July the number of tests increased more in Bangladesh, as of $6^{\text {th }}$ August 2020 the number of tests performed 12,708 and 2,977 new cases are found. A total of 12,25,124 tests have been performed according to IEDCR so far in Bangladesh, which is still inadequate based on the number of people we have in Bangladesh.

\subsection{Bangladesh's Capacity of Fighting COVID-19 and Health System}

Due to the overpopulated country, Bangladesh is a convenient land for infectious diseases. Except for proper vaccination programs, this country has not established public health as well as sufficient capacity for clinical management against infectious disease. Our abilities on both 'stable stage' (i.e., prepared HR and foundation) and embodiment of 'quick factors' (i.e., isolate and disconnection units) for quick crisis reaction dealt with the rising irresistible pandemic situation were genuinely missing, too. Even though it was another malady the RT-PCR which is a work concentrated technique was begun soon with quick expansion to over 50 focuses in a brief timeframe. The utilization of the test for contamination control and concealment of transmission is a scourge [22].

In Figure 3, it is summarized that the degrees of different sorts of therapeutic administration workers are in each division. In practically all the divisions, masters structure the greatest degree of therapeutic administration staff followed by orderlies. An exemption is the Rajshahi Division where the extent of medical caretakers surpasses the extent of specialists. Sylhet and Khulna appear to have almost equivalent extents of specialists and medical attendants. The extent of clinical technologists seems, by all accounts, to be most elevated in Mymensingh and least in Sylhet and Rajshahi. Aside from specialists, attendants, and clinical technologists, there are other supporting clinical staff, for example, ward young men, cleaners, and so on who include essential jobs inside the medicinal services framework.
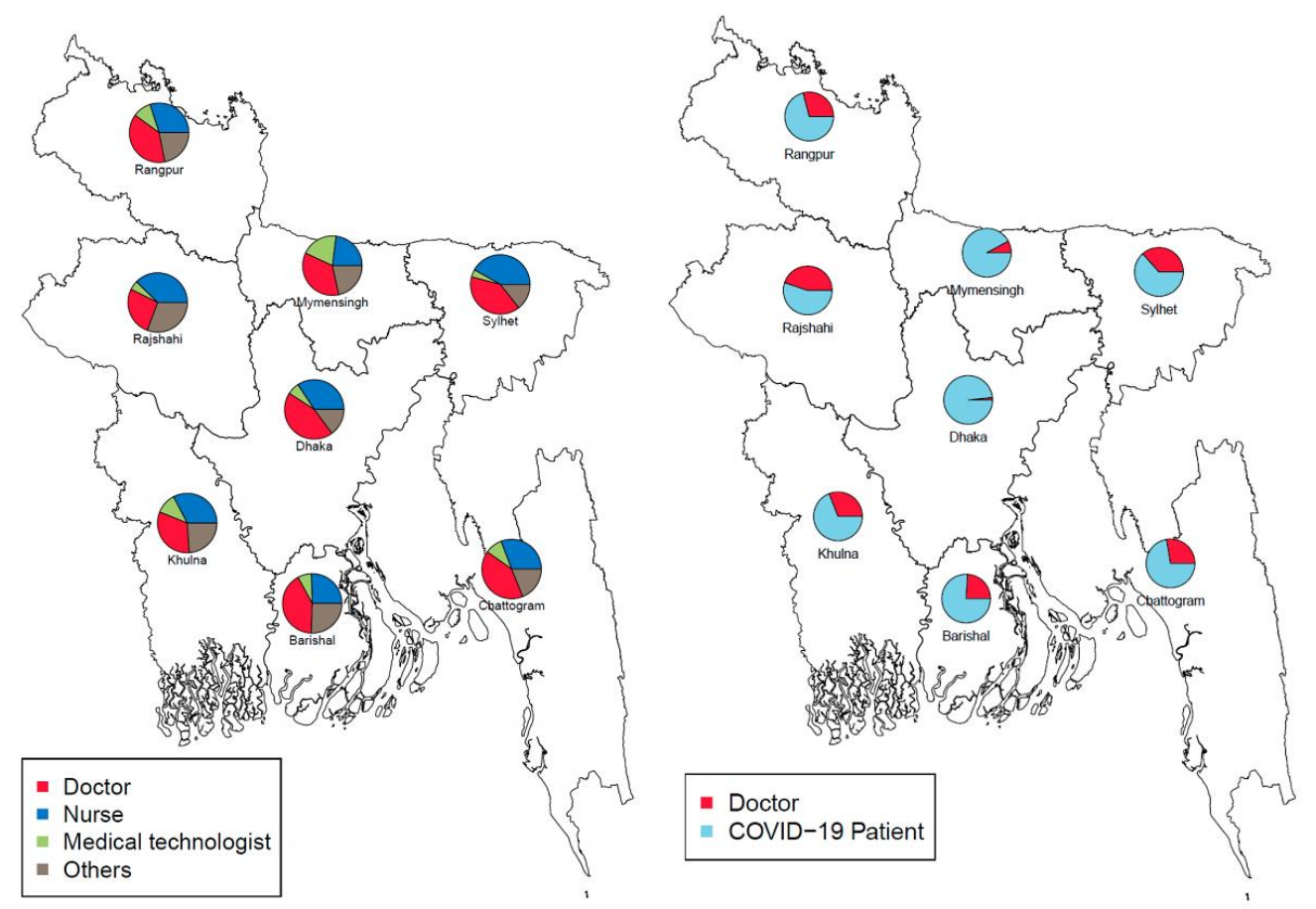

Figure 3. Division-wise conveyance of health care staff (left board) and proportion of COVID-19 patients and specialists in the divisions of Bangladesh (right board) [3] 
A noteworthy extent of social insurance laborers has a place with this gathering in all the divisions [12]. This is especially obvious in the Rajshahi Division where the extent of social insurance laborers having a place with the 'Others' class surpasses the extent of specialists. Figure 3 (right part) shows the extent of the quantity of COVID-19 patients to the number of experts open to regard them for each division according to data up to August $10^{\text {th }}$. One upsetting finding is the exorbitantly unobtrusive number of pros practically identical to the number of cases in the Dhaka Division achieving a high extent. The suggestion is a high danger of the social insurance framework being overpowered because of the intense lack of specialists, who structure the cutting edge barrier in the battle against the pandemic. Mymensingh Division may moreover be in a powerless circumstance due to the number of pros being about $10 \%$ of the amount of COVID-19 patients. Barisal Division, which has the most negligible number of cases, appears to have about a quarter yet the extent could without a very remarkable stretch addition if the number of cases rises and more pros can't be given to treat these cases [3]. A comparable circumstance exists in Chittagong Division also. On the other hand, Sylhet, Khulna, and Rangpur have littler proportions and in this manner give off an impression of being in a superior situation to deal with the emergency. Rajshahi division is in the best situation to deal with the emergency [23].

\subsection{Lockdown Policy of Bangladesh by Month}

\subsubsection{Earlier Stage}

Bangladesh forced an across the nation lockdown Tuesday to control the spread of the novel coronavirus in the wake of four passing and at any rate 39 contaminations. Specialists announced a restriction on traveler travel through water, rail, and on residential air courses from March 24 while all open vehicles on streets will be suspended from March 26 to stem the spread of the infection, formally known as COVID-19. A large number of Bangladeshis like to travel every day by ship and traveler pontoons, particularly those in the nation's southern areas. The Bangladesh Railway Authority has likewise suspended all nearby, suburbanite, and mail train benefits the nation over until further notification. The legislature additionally chose to suspend all household business departures from midnight. Tuesday until further notice as a major aspect of endeavors to urge individuals to remain at home to contain the episode. Fear is growing for responding to the COVID-19 situation and people are afraid to face the crisis [20]. Furthermore, the Department of Immigration and Passports on Monday suspended new enlistments for both electronic and machine clear travel papers until further notification while offering extraordinary game plans for earnest cases. The conclusion of every single instructive foundation in the nation has been reached out to April 9 from March 31 already, the Ministry of Education said in an announcement. In the interim, Bangladesh's primary sending out instant piece of clothing (RMG) division is bringing about a tremendous shortage. To guarantee the flexible chain and economical market costs, the administration on Tuesday additionally dropped all leaves and excursions for government authorities under the Ministry of Commerce who are answerable for observing nearby markets. Then, China has chosen to help Bangladesh by sending Personal Protection Equipment (PPE) and test units amid a deficiency in the nation. Low-pay laborers in the capital Dhaka, be that as it may, have been leaving the city by different methods amid a high danger of coronavirus disease following the prohibition on trains and other open vehicle administrations. Several such suburbanites were seen leaving the city Tuesday night, involving the tops of open transports and trucks in Dhaka's business center point of Motijheel infringing upon government directions.

\subsubsection{Lockdown Stage}

Bangladesh on Tuesday broadened the national shut down until April $11^{\text {th }}$ to stem the spread of the coronavirus in the nation. The choice came as two more COVID-19 cases took Bangladesh's count to 51 on Tuesday [10]. The nation of around 165 million individuals has so far announced five passing due to the coronavirus. Govt. prior reported a 10day general occasion from March 26 and it is currently reached out for five days until April $9^{\text {th }}$. Bangladesh government also circumvents the event of Bangabandhu Sheikh Mujibur Rahman's 100th birth anniversary in which India's Prime Minister Modi was invited as the chief guest. The premier also warned of an impending global financial crisis due to the disruption of economic activity caused by the COVID-19 pandemic [3, 18]. Bangladesh has broadened an across the country lockdown till May $5^{\text {th }}$ as a feature of measures to stem the spread of coronavirus pandemic, nearby media announced. According to the Daily Jugantor, the State Minister for Public Administration Ministry Farhad Hossain said "Occasions will be stretched out till May $5^{\text {th }}$ from April $26^{\text {th }}$. The assembly will give a paper in such a way like". The pastor, notwithstanding, included that May $6^{\text {th }}$ is likewise an administration occasion because of the strict ceremonies of the nation's minority Buddhist people group, or Buddhist Full Moon occasion. The South Asian nation of more than 165 million people has so far nitty-gritty 120 passing from the disease as of Wednesday, with 3,772 avowed cases and 92 recoveries. As indicated by the official information, a sum of 32,674 individuals have been tried since the first coronavirus case was detailed in the nation on March 8 .

\subsubsection{Situation after Lockdown}

Bangladeshi specialists reported on Tuesday, June 16, that worldwide flight tasks would continue at a constrained scale in the midst of the facilitating of coronavirus ailment (COVID-19) limitations. Hygiene and social distancing 
measures have been put in place throughout Bangladesh's airports. Bangladesh government has declared Cox's Bazar (Chittagong division) as a red zone from June $6^{\text {th }}$ until June $20^{\text {th }}$ and put unconditional lockdown constraints on the region. All shops will be shut during this period aside from food markets, which are allowed to open on Sundays and Thursdays as it were. Also, travel into and out of the town isn't allowed during this period. As of Wednesday, June 17, wellbeing specialists have affirmed 94,481 COVID-19 cases and 1262 related passing in China. Further spread of the infection is normal in the close term. The administration of Bangladesh has set a region of Dhaka under a three-week lockdown between Saturday, July $4^{\text {th }}$, and Saturday, July $25^{\text {th }}$, to control the spread of the coronavirus ailment (COVID-19). The choice to lock downward 41 in the area of Wari was made after 46 instances of COVID-19 were distinguished in the region before the finish of June. Blockades have been set up around 21 streets in the zone and the main two different ways all through the ward are being kept an eye on by security powers. Inhabitants may be permitted to leave the region for crisis reasons and all shops separated from drug stores have been shut, alongside schools and both open and private organizations. The law enforcement department has been conveyed to implement the lockdown and neighborhood authorities will organize the conveyance of food to the ward. Bangladeshi specialists reported on June $30^{\text {th }}$ that the limitations set up to contain the spread of COVID-19 have been stretched out until August $3^{\text {rd }}$. Check-in time hours have been abbreviated to somewhere in the range of 22:00 and 05:00 (neighborhood time). In any case, all superfluous travel stays restricted. The wearing of face veils and social separating measures likewise stay mandatory out in the open spots, while a prohibition on rallies, gatherings, and mass get-togethers stay set up. Open transportation has been permitted to work in certain districts at a diminished limit. As of Tuesday, July 7 , wellbeing specialists have affirmed 168,645 COVID-19 cases, with 2151 related passing in the nation. Further spread of the infection is normal in the close to term [4].

\section{Discussions}

\subsection{General Advice for Risk Mitigation}

Measures got by neighborhood experts advance quickly and are commonly producing results at this moment. Dependent upon the headway of the scene in various countries, masters are most likely going to alter, at amazingly an astonishing piece of news, the once-over of countries whose voyagers are at risk to edge control measures or section constraints upon their appearance to the locale being alluded to. It is urged to concede immaterial travel because of the peril that explorers may be declined section or be obligated to separate upon their appearance or during their remain [24].

To diminish the threat of COVID-19 transmission, voyagers are urged to keep up the going with measures:

- Cleaning hands by applying an alcohol-based hand rub or washing with soaps;

- During coughing and sneezing, spread the mouth and nose with a flexed elbow or tissue; at whatever point is used, dispose of the tissue speedily and wash hands. For this cause, the safest way is using a mask;

- Maintaining the safest distance from people to people and avoiding the crowded place.

On account of experiencing a fever, hack, inconvenience breathing, or some opposite symptoms suggestive of a respiratory disorder, including pneumonia, call telemedicine offices before embarking to the masters or crisis facility to thwart the normal spread of the disease.

\subsection{Suggestions for Improvement}

- Opening Markets and shopping malls with proper guidelines for health safety;

- Preventing people from movement during vacation for Eid or other religious occasions;

- Construct proper guidelines by the Government regarding the opening of garments with proper health safety and follow them strictly;

- Doing an adequate amount of COVID-19 tests comparing the massive population of Bangladesh;

- The Ministry of Health should take exemplary steps for the COVID-19 patients and their treatment avoiding any kind of corruption as JKG Bangladesh and Regent hospital are perfect examples;

- Doing a massive COVID-19 test for all the suspected people is recommended;

- Making strict laws about wearing masks in public places could stop spreading the virus a lot;

- Restricting people going outside from home, where COVID-19 positive people are at an alarming rate, i.e. proper lockdown on clusters of COVID-19 patient's zone is needed. 


\subsection{Social Response in Bangladesh during COVID-19 Pandemic}

The first corona case was identified in Bangladesh in March 2020. As the confirmed cases and death rate had been increasing continuously, to ensure the health safety of the citizens, the government had taken a complete lockdown all over the country, restricted movements temporarily closed many shops, and many more. Citizens were encouraged to maintain social distancing, self-isolation, and travel restrictions. Many people were coming back to the country from abroad, as the situation was getting worse day by day in many other countries. The government declared home quarantine mandatory for them. Though the government was claiming that they are ready to handle the pandemic, but, many of the ministers were saying that the pandemic is making the government uncomfortable (The Daily Star, 2020). In earlier, Bangladesh was facing problems due to a lack of corona dedicated hospitals, testing kits, and PPEs for doctors and nurses. On $26^{\text {th }}$ March, the administration initially presented a multi-day shutdown. Besides, later, it was stretched out until $10^{\text {th }}$ April. What's more, on $10^{\text {th }}$ April, the administration broadened this progressing general occasion of all open and private workplaces until $25^{\text {th }}$ April. On $13^{\text {th }}$ May, it was represented that the organization is most likely going to extend the shutdown of large private and open workplaces until $30^{\text {th }}$ May. Medical clinics, kitchen markets, tranquilize stores, and other fundamental administrations, in any case, stayed open. On $1^{\text {st }}$ April, the authorities dropped each open program checking Pahela Baishakh, the Bengali New Year, to dodge mass get-togethers as a significant part of its undertakings to contain the spread of the novel coronavirus (Dhaka Tribune, thirteenth April 2020). The readymade articles of the clothing industry resemble an impetus for the economy of Bangladesh. The BGMEA was constantly observing the circumstance in the article on clothing production lines [25]. Because of this pandemic, 1136 factories announced that they have lost \$3.15billion in dropped or deferred orders, which is proportional to 976 million pieces. On average 2.26 million workers are influenced so far for the most part not getting their salary [24].

\subsection{Social Distancing is Unmanageable in Several Areas of Bangladesh}

As referenced already, Bangladesh didn't compel any extraordinary show from the start, and a tremendous number of individuals were out in the city, particularly in Dhaka, which is a megacity with 46 thousand individuals living for each square kilometer [26]. Social distancing is extreme while taking open drives and living in the ghettos. Concerning profoundly populated and cut down focus pay countries like Bangladesh, the prerequisite of social expulsion as endorsed by the WHO to stop the nCoV-2 spread sounds extreme yet unreasonable. Without a doubt, remaining at home is probably not going to be as viable here. Dhaka, the capital of Bangladesh, is distant from everyone else home to some 1.1 million ghetto inhabitants [16]. These ghetto tenants, the majority of whom have never gone to class and at present lived in slums, are not mindful of the danger from nCoV-19. The range of family unit profit of ghetto inhabitants in Dhaka is around BDT 8,000 per month (less than 100 USD per month), and they use around $70 \%$ of their income on food and lodging [18]. Except for any doubt, even a 400-mL compartment of hand concoction per ghetto, which costs around 80 BDT ( 1 USD), is hard for them to administer. Also, every 10-16 families approach as they say one washroom/toilet, where there is no standard easily of water [18, 24]. Close by the slum dwellers, Bangladesh moreover has over a million Rohingya outsiders, most of whom are living front and center quarters in Rohingya camps where the cleansing workplaces are in fact, even meager [25]. The dread of COVID-19 is now outfitting among the dislodged individuals in these camps. Prompt authorization of social separating is, all around, for all intents and purposes incomprehensible in a nation like Bangladesh.

\section{Conclusion and Recommendations}

Even though the government is taking measures against COVID-19, public perception is quite negative according to the data. Why is this different? Is it largely due to misinformation or rumors or is it due to delayed response by the government? It is difficult to draw a sudden conclusion. Because survey responses were relatively low. But several assumptions can be made that may lead to future research in a related field. Data suggest that the government's response began late. When the world began to experience its deadliest in Italy, people responded rapidly. The Prime Minister's initial address to the nation can make the situation easier and people will get a comprehensive policy guideline. On the other hand, a large gap in coordination between ministries was visible. This study places importance on the picture which has changed since the speech of our Honorable Prime Minister. For example, more hospitals were included, test kits were imported, PPE was distributed to doctors and others. Even a government bailout plan was largely unknown until its first address. So, this study thinks that in the event of this epidemic, the policy of the government should be scorned by the Honorable Prime Minister towards the country, so that people can understand more and participate in the battlefield against this virus along with the government [24, 25]. The Ministry of Health concerned, the Ministry of Health, significantly failed to inform the people; they could not understand the demand of the public and they failed to tell the people what measures the government had taken. The Ministry of Information is also partly responsible for not sharing the measures taken by the government. This increased a vacuum and facilitated the spread of rumors on social media. Therefore this research suggests some policy tips fight COVID-19. 
First, the policy of the government should be reported directly to the media by the Honorable Prime Minister.

Secondly, the government should immediately form a scientific advisory board headed by a scientist and which specifically includes scientists, academics, doctors, and researchers. This body will be accountable to the Prime Minister only. The National Committee of the Government will make a decision based on the recommendations of the said group;

Third, more tests should be confirmed every day. Through rigorous testing across the country, we will know who to treat and who to isolate and keep aside. Lack of testing will lead us to a catastrophic situation. Also, special hospitals designed for patients should be equipped with at least 1000 ventilators. If it is difficult to buy, the government can bring ventilators on 'loan';

Fourth, Bangladesh has announced a bailout scheme of more than 72 thousand crores, but these packages did not tell us how low-income people or poor people and farmers would be facilitated. This research suggests that a separate bailout policy should be implemented for farmers as there is no interest policy;

Fifth, hospitals should work in collaboration. It has been reported that many private hospitals have limited services for the general public in addition to COVID 19 that raises health concerns. Each major hospital should be kept open with proper protection for frontline doctors and nurses, and treatment should continue. Besides, more hospitals should have well-equipped areas with ventilators for proper isolation over a critical period. In addition to specialized hospitals in Dhaka, each division must have at least one special hospital;

Sixth, low-income people should be taken care of with utmost importance. Those who do not have a fixed income will be vulnerable in the event of a lockdown. Therefore, both the public and private sectors should come forward to assist them with assistance;

Seventh, garment factories should be closed for at least more than a month. The current lockdown should continue until the end of April. This will facilitate social disturbances and reduce the chances of getting infected. Local and community broadcasting will be reduced through this measure;

Finally, the government should urge people of all sects to cooperate in fighting COVID-19. It is not the only task of the government to fight this war. Social awareness campaigns should be continued through print, electronic and social media. Kovidd-19 i.e. an important tool for dealing with social disturbances should be made more popular among the people.

\section{Declarations}

\subsection{Author Contributions}

M.T.A. and M.A. developed the idea, prepared the research methodology model; M.T.A. and N.N.S. contributed to finding online resources for data collection and prepared the questionnaire; M.T.A., N.N.S., M.A. helped to collect data from the context of Bangladesh; M.T.A., N.N.S. and M.A. contributed to the design and implementation of the research, to the analysis of the results; F.A.J. and M.A.R. assisted with other authors to prepare the manuscript in a proper format. All authors have read and agreed to the published version of the manuscript.

\subsection{Funding}

The authors received no financial support for the research, authorship, and/or publication of this article.

\subsection{Acknowledgments}

The authors would like to acknowledge the support from the Biomedical Engineering Department, Military Institute of Science and Technology (MIST), Bangladesh.

\subsection{Ethical Approval}

The manuscript does not contain experiments on animals and humans; hence ethical permission not required.

\subsection{Data Availability Statement}

Some data associated with this research is available in Appendix I. Other global and national data is available on request from the corresponding author.

\subsection{Conflict of Interest}

The authors declare that they have no known competing financial interests or personal relationships that could have appeared to influence the work reported in this paper. 


\section{References}

[1] IEDCR/DGHS/GoB, (2020). Coronavirus COVID-19 Dashboard. Available online: http://103.247.238.81/webportal/pages/ covid19.php?fbclid/4IwAR0fvp1tINehCpQfHn8c61CqwqMmjNncdLdhNqYLIsMAhaSxD2nM4Jd043Y (accessed on January 2021).

[2] Xiao, H., Zhang, Y., Kong, D., Li, S., \& Yang, N. (2020). Social Capital and Sleep Quality in Individuals Who Self-Isolated for 14 Days during the Coronavirus Disease 2019 (COVID-19) Outbreak in January 2020 in China. Medical Science Monitor, 26. doi: $10.12659 / \mathrm{msm} .923921$.

[3] Bangladesh Bureau of Statistics. Population and Housing Census 2011 National volume 2: Union Statistics. Dhaka (2015). Available online at: http://bbs.dhaka.gov.bd/sites/default/files/files/bbs.dhaka.gov.bd/law_policy/6ed6b42c_2015_11e7_8f57 _286ed488c766/Socio-Economic\%20and\%20demographic\%20Report\%202012.pdf (accessed on April 2021).

[4] Molla MA-M (2020). Govt Now Scrambles for Testing Kits, PPE. Available online: https://www.thedailystar.net/frontpage/ news/govt-now-scrambles-testing-kits-ppe-1882633 (accessed on January 2021).

[5] Fernandez-Villaverde, J., and Jones, C. I. (2020). Macroeconomic Outcomes and COVID-19: A Progress Report. NBER Working Paper 28004, National Bureau of Economic Research, Cambridge, MA.

[6] TBS, (2020a). Fear, Hatred and Stigmatization Grip Bangladesh amid Covid-19 outbreak. In: Archived Newspaper the Business Standard. Available online: https://tbsnews.net/thoughts/fear-hatred-and-stigmatization-grip-bangladesh-amid-covid-19outbreak-61129 (accessed on December 2020).

[7] TBS, (2020b). Coronavirus Cases Detected in Cox's Bazar Rohingya camps. In: Archived Newspaper the Business Standard. Available online: https://tbsnews.net/coronavirus-chronicle/bangladesh-says-coronavirus-detected-rohingya-refugee-camp81490?fbclid1/4IwAR024QrrPPYSK_9WzfaMpTHCJu7hemZ1UzFpAQaKnyBxyQ7QV-YoJOTQjGY (accessed on December 2020).

[8] BTRC, 2020. Internet Subscribers in Bangladesh. Available online: http://www.btrc.gov.bd/content/internet-subscribersbangladesh-february-2020 (accessed on September 2020).

[9] bdnews24.com (2020). Army to Run Coronavirus Quarantine Units in Dhaka's. Available online: https://bdnews24.com/bangladesh/2020/03/20/army-to-run-coronavirus-quarantine-units-in-dhakas-ashkona-diabari (accessed on March 2020).

[10] The Daily Star (2020). Coronavirus Test in 15 mins for Tk 350. (2020). Available online: https://www.thedailystar.net/ backpage/news/coronavirus-test-15-mins-tk-350-1882597 (accessed on March 2020).

[11] The Financial Express (2020). RMG Workers Returning Dhaka to Save Jobs amid Virus Fear. Available online: https://thefinancialexpress.com. bd/national/rmg-workers-returning-dhaka-to-save-jobs-amid-virus-fear-1586003905 (accessed on April 2020).

[12] CBC News (2020). Canada Refuses to Approve Rapid Coronavirus Blood Test. Available online: https://www.cbc.ca/player/play/1722212931886 (accessed on April 2020).

[13] Durmuş, H., Gökler, M. E., \& Metintaş, S. (2020). The Effectiveness of Community-based Social Distancing for Mitigating the Spread of the COVID-19 Pandemic in Turkey. Journal of Preventive Medicine and Public Health, 53(6), 397-404. doi:10.3961/jpmph.20.381.

[14] Baker, S. R., Bloom, N., Davis, S. J., \& Terry, S. J. (2020). COVID-Induced Economic Uncertainty (Working Paper No. 26983; Working Paper Series). National Bureau of Economic Research. doi:10.3386/w26983.

[15] Gao, J., Zheng, P., Jia, Y., Chen, H., Mao, Y., Chen, S., ... Dai, J. (2020). Mental health problems and social media exposure during COVID-19 outbreak. PLOS ONE, 15(4), e0231924. doi:10.1371/journal.pone.0231924.

[16] Maswood MH, Chowdhury SI. (2020). Bangladesh Bans Travellers' Entry from Europe. Available online: https://www.newagebd.net/article/102202/ bangladesh-bans-travellers-entry-from-europe (accessed on April 2020).

[17] Dhaka Tribune. (2020). Coronavirus: Overseas Returnees Roaming Around Violating Govt Directive, Hundreds Fined. Available online: https://www.dhakatribune.com/bangladesh/nation/2020/03/19/expats-roaming-around-in-quarantinehundreds-fined-over-a-million-taka (accessed on September 2020).

[18] Mahmud F. (2020). Bangladesh Founder's Birth Centenary Event Postponed. Available online: https://www.aljazeera.com/ news/2020/03/coronavirus-bangladesh-founder-birth-centenary-event-postponed-20030911345962 9.html (accessed on April 2020).

[19] bdnews24.com. (2020). Bangladesh to Ban All Rallies after Coronavirus Advice Defied. Available online: https://bdnews 24.com/bangladesh/2020/03/20/bangladesh-to-ban-all-rallies-after-coronavirus-advice-defied (accessed on April 2020). 
[20] Chowdhury T. (2020). Fears Grow Over Bangladesh's COVID-19 Response. (2020). Available online at: https://www.alja zeera.com/news/2020/03/fears-grow-bangladeshs-covid-19-response-200323111803294.html (accessed on April 2020).

[21] Dhaka Tribune. (2020). Covid-19: Immediate Expansion of Testing Labs to Districts Needed. (2020). Available online at: https://www.dhakatribune.com/health/coronavirus/2020/04/11/covid-19-immediate-expansion-of-testing-labs-to-districtsneeded (accessed on April 2020).

[22] Rana BJ, Sakka HEl, (2020). WHO-BAN. COVID-19 Situation Report No 06. Available online: https://www.who.int/docs/default-source/searo/bangladesh/covid-19-who-bangladesh-situation-reports/who-ban-covid-19sitrep-06.pdf?sfvrsn=36254da0_6 (accessed on June 2020).

[23] Latif, M. B., Irin, A., \& Ferdaus, J. (2016). Socio-economic and health status of slum dwellers of the Kalyanpur slum in Dhaka city. Bangladesh Journal of Scientific Research, 29(1), 73-83. doi:10.3329/bjsr.v29i1.29760.

[24] Hamid, A. R. A. H. (2020). Social responsibility of medical journal: a concern for COVID-19 pandemic. Medical Journal of Indonesia, 29(1), 1-3. doi:10.13181/mji.ed.204629.

[25] Van Bavel, J. J., Baicker, K., Boggio, P. S., Capraro, V., Cichocka, A., Cikara, M., ... \& Willer, R. (2020). Using social and behavioural science to support COVID-19 pandemic response. Nature human behaviour, 4(5), 460-471. doi:10.1038/s41562020-0884-z

[26] The Financial Express. (2020). RMG Workers Returning Dhaka to Save Jobs Amid Virus Fear. Available online: https://thefinancialexpress.com.bd/national/rmg-workers-returning-dhaka-to-save-jobs-amid-virus-fear-1586003905 (accessed on March 2020) 


\section{Appendix I: The list of new hospitals that are treating COVID patients}

- Evercare Hospital, Dhaka

- Square Hospital, Dhaka

- Ibn Sina Medical College Hospital, Dhaka

- Anwar Khan Modern Medical College Hospital, Dhaka

- Enam Medical College and Hospital, Dhaka

- United Hospital Limited, Dhaka

- Lab aid Hospital, Dhaka

- Aichi Hospital Limited, Dhaka

- Zainul Haque Shikder Women's Medical College \& Hospital(PVT) Ltd., Dhaka

- AMZ Hospital Limited, Dhaka

- Universal Medical College and Hospital, Dhaka

- Ahsania mission Cancer and General Hospital, Dhaka13 Bangladesh Institute of Health Sciences General Hospital, Dhaka

- Imperial hospital Limited Chottogram

- Brahmanbaria medical College Hospital Brahmanbaria

- TMSS Medical College Hospital and Rafatullah Community Hospital Bogura

- Dr. Farida Huq Memorial Ibrahim General Hospital COVID-19 Gazipur Diagnostic Lab

- International Medical College Hospital, Gazipur

- Sheikh Fazilatunnesa Mujib Memorial KPI Specialized Hospital and Nursing College, Gazipur.

- Praava Health Bangladesh Ltd. Dhaka

- Biomed Diagnostics, Dhaka.

- DMFR Molecular Lab and Diagnostics, Dhaka

- DNA solution Limited, Dhaka.

- CSBF Health Centre, Dhaka

- Dr. Lal Path Labs Bangladesh Pvt. Ltd., Dhaka

- The DNA Lab Limited, Dhaka

- Gulshan Clinic Limited, Dhaka

- Authentic Diagnostics \& Consultation Ltd., Dhaka

- CHL Diagnostics, Dhaka

- icddr,b Molecular Diagnostic Laboratory, Dhaka

- Aalok Healthcare Ltd., Dhaka

- Chevron Clinical Laboratory (PTE) Ltd. Chottogram

- Gazi COVID-19 PCR Lab, Rupganj Narayanganj 